\title{
Prediction of Manure and Nutrient Excretion from Dairy Cattle
}

\author{
T. D. Nennich, ${ }^{1}$ J. H. Harrison, ${ }^{1}$ L. M. VanWieringen, ${ }^{1}$ D. Meyer, ${ }^{2}$ A. J. Heinrichs, ${ }^{3}$ \\ W. P. Weiss, ${ }^{4}$ N. R. St-Pierre,${ }^{5}$ R. L. Kincaid ${ }^{6}$ D. L. Davidson, ${ }^{1}$ and E. Block ${ }^{7}$ \\ ${ }^{1}$ Puyallup Research and Extension Center, Washington State University, Puyallup 98371 \\ ${ }^{2}$ Department of Animal Sciences, University of California, Davis 95616 \\ ${ }^{3}$ Department of Dairy and Animal Science, The Pennsylvania State University, University Park 16802 \\ ${ }^{4}$ Department of Animal Sciences, Ohio Agriculture Research and Development Center, \\ The Ohio State University, Wooster 44691 \\ ${ }^{5}$ Department of Animal Sciences, The Ohio State University, Columbus 43210 \\ ${ }^{6}$ Department of Animal Sciences, Washington State University, Pullman 99163 \\ ${ }^{7}$ Church \& Dwight Co. Inc., Princeton, NJ 08543
}

\begin{abstract}
Accurate estimates of manure excretion are needed for planning manure storage facilities and for nutrient management. Data sets from metabolism studies conducted at several universities were compiled and evaluated for excretion of total manure, N, P, and K. Animal groups included calves weighing up to $204 \mathrm{~kg}$, heifers weighing between 274 and $613 \mathrm{~kg}$, nonlactating cows, and lactating cows. Regression equations were developed to predict excretion of total manure, total dry matter, N, P, and K. Predictors used in the regression equations for lactating cows included milk yield, percentages of protein and fat in milk, dietary concentrations of crude protein and neutral detergent fiber, and intakes of nutrients. The regression equations provide improved predictions of excretion and enable more accurate planning of manure storage and nutrients to be managed at the farm level.
\end{abstract}

(Key words: manure, nitrogen, phosphorus, potassium)

Abbreviation key: ASAE = American Society of Agricultural Engineers, $\mathbf{D M D}=\mathrm{DM}$ digestibility, $\mathbf{D M}_{\mathbf{E}}=$ manure DM excretion, $\mathbf{K}_{\mathbf{E}}=\mathrm{K}$ excretion, $\mathbf{M}_{\mathbf{E}}=$ manure excretion, $\mathbf{M F}=$ milk fat percentage, $\mathbf{M I L K}=$ milk yield, MilkP $=\mathrm{P}$ in milk, $\mathbf{M T P}=$ milk true protein, $\mathbf{N}_{\mathbf{E}}=\mathrm{N}$ excretion, $\mathbf{P}_{\mathbf{E}}=\mathrm{P}$ excretion.

\section{INTRODUCTION}

Accurate estimates of manure and nutrient excretion are important for designing adequate manure storage facilities and developing effective nutrient management plans. Recent modifications to the Clean Water

Received December 22, 2004.

Accepted June 14, 2005.

Corresponding author: Joseph Harrison; e-mail: jhharrison@ wsu.edu.
Act have resulted in new regulations related to nutrient management on concentrated animal feeding operations (Environmental Protection Agency, 2003). It is expected that concentrated animal feeding operations will develop nutrient management plans that include designs for collection and storage of manure, as well as strategies for land application of manure at agronomic rates. According to the Natural Resources Conservation Service standard for nutrient management planning (NRCS, 2001), nutrient budgets should be established for N, P, and K. In addition, estimates of manure DM excretion are useful for designing manure treatment and handling technologies such as anaerobic digesters, or for the development of future manure treatment technologies.

Estimates for manure and nutrient excretion by dairy cattle are found in the American Society of Agricultural Engineers (ASAE) Standard D384.1 (ASAE, 2001). These estimates are limited in their utility and accuracy as they are based on data from the late 1960s and early 1970 s, and were taken from a data set that was of limited known origin. In addition, the ASAE standard was revised in 1988 to merge a dairy heifer column with a dairy cow column for one single column for all dairy cattle categories.

Recent reports of excretion data from dairy cows were compiled from lactating Holstein dairy cows producing an average of 20.3 and $29 \mathrm{~kg}$ of milk/d (Tomlinson et al., 1996; Wilkerson et al., 1997). Today, many dairy cattle are producing milk at twice those levels. Contemporary manure and nutrient excretion estimates are needed to more precisely predict excretion from higher producing cows. Most important, equations need to be developed to reflect the relationship between milk production and manure or nutrient excretion.

Previous evaluations of manure excretion from dairy cattle indicated that the ASAE (2001) manure excretion estimates underestimated excretion from high-producing cows (Tomlinson et al., 1996) and that using only 
BW is not an accurate method of predicting manure or nutrient excretion (James et al., 1999). As production and management of dairy cattle have changed in recent decades, changes may also have occurred in manure and nutrient excretion. In addition, excretion estimates for calves and heifers have not been published in recent years. Feed consumption (quality and quantity) differs from young calves to springing heifers. It is reasonable to assume that BW alone is not a good predictor of manure and nutrient excretion for all heifer categories. As an example, dairies with high culling rates and approximately equal number of replacement heifers as lactating cows need to have precise estimates for manure and nutrient excretion to adequately establish a nutrient plan. Furthermore, heifer data are essential for replacement heifer operations. Technical assistance providers, dairy operators, and staff from regulatory agencies are seeking site-specific information on manure volume and nutrient content to more precisely develop nutrient management plans and design adequate manure storage systems. Updated information is critical to owners of animals residing in environmentally sensitive areas.

In 2001, a committee was developed by the ASAE Structures and Environment Committee 412 and members from the Federation of Animal Science Societies to revise the ASAE manure excretion values using data from contemporary diets and levels of productivity (ASAE Standard Tables D384.1). The committee structure consisted of animal species subgroups, which included dairy cattle. The outcomes of the dairy subgroup's efforts are reported in this paper. The overall goal of the dairy subgroup's effort was to evaluate data collected from studies with contemporary diets that represented a broad geographical context and included data from cows milking $>40 \mathrm{~kg}$ of milk per day. The primary objectives of the dairy subgroup were to develop regression equations to predict manure, DM, and nutrient excretion of calves, heifers, and nonlactating and lactating Holstein dairy cows, and to document nutritional parameters associated with manure and nutrient excretion.

\section{MATERIALS AND METHODS}

Data sets from Washington State University, The Ohio State University, The Pennsylvania State University, and the University of California, Davis were combined and used for estimations of excretion from dairy cattle (Table 1). The overall data set included records from a wide variety of animal ages, ranging from calves to multiparous lactating cows. Data were categorized into 4 groups: lactating cows (LACT), dry cows (DRY), heifers (HEIFER), and calves (CALF). The LACT data set (554 cows or cow-periods from Latin square experiments) included multiparous lactating Holstein cows. The DRY data set (18 cow-periods) animals were defined as multiparous, nonlactating cows that were pregnant. The HEIFER data set (60 animal-periods) included female, nonlactating animals that had not calved and included animals of various ages weighing $>250 \mathrm{~kg}$. The CALF data set (46 animal-periods) included animals weighing $<250 \mathrm{~kg}$ (Table 2 ).

The LACT data set included observations from 26 individual feeding studies. Most feeding studies were originally intended to evaluate nutritional hypotheses. The California studies were designed specifically to evaluate the applicability of ASAE Standards under California conditions. Variation in animal location and dietary ingredients increased the errors associated with development of regression equations, but provided a broader base to account for differences in the commercial industry. An effort was made to include several equations for each dependent variable during the development of prediction equations to provide users flexibility depending on the accuracy and availability of input variables for a given dairy operation.

The independent variables included in the LACT data set were BW, DIM, DMI, DM digestibility (DMD), milk yield (MILK), percentage milk fat (MF), and percentage milk protein (Table 3). Milk CP values in the data set were converted to milk true protein (MTP) values using a conversion factor of 0.9345 (Mackle et al., 1999). Dietary ingredients and characteristics were used as additional prediction factors for equations, including dietary concentrations of CP, NDF, P, and K. Dependent variables included in the LACT data set were (Table 3) manure excretion $\left(\mathbf{M}_{\mathbf{E}}\right), \mathrm{DM}$ excretion $\left(\mathbf{D M}_{\mathbf{E}}\right), \mathbf{N}$ excretion $\left(\mathbf{N}_{\mathbf{E}}\right)$, P excretion $\left(\mathbf{P}_{\mathbf{E}}\right)$, and $\mathrm{K}$ excretion $\left(\mathbf{K}_{\mathbf{E}}\right)$. Dry matter excretion included both fecal and urinary $\mathrm{DM}$ and was determined by adding actual fecal DM and $4.5 \%$ of urinary excretion.

Quadratic models were evaluated for excretion variables using the LACT data set. Variables evaluated in equations included squared and 2-way interactions of DMI, MILK, DIM, BW, and dietary NDF and CP concentrations.

Data on $\mathrm{P}$ and $\mathrm{K}$ intake and excretion for lactating animals were only available for a subset of animals in the LACT data set. The MINERAL data set (85 cowperiods) included cows for which excretion of feces and urine were known. Intakes of minerals were determined through analyses of both feed and orts. One study of early lactation cows (Johnson et al., 1998, experiment $2 ; 15$ cow-periods ranging from 16 to 61 DIM) was not included in the MINERAL data set due to negative $\mathrm{P}$ and $\mathrm{K}$ balances for the early lactation animals. 
Table 1. Experiments included in the data sets used for development of excretion equations.

\begin{tabular}{|c|c|}
\hline Data source & Experiment source or description \\
\hline Washington State University & $\begin{array}{l}\text { Published experiments } \\
\text { Johnson et al., } 1998 \\
\text { Timmermans et al., } 2000 \\
\text { Description of unpublished experiments } \\
\text { 1. Treatments included fish meal or distillers grain plus } \\
\text { an additional protein supplement. The study was a } \\
\text { switchback design and included } 4 \text { multiparous lactating } \\
\text { Holstein cows }(2 \text { cows per treatment per period). Sam- } \\
\text { ples of feed, orts, feces, and urine were collected for the } \\
\text { last } 4 \text { d of each period and composited on a weight basis. } \\
\text { 2. Dry rolled corn or high moisture corn or } 2 \text { combinations } \\
\text { of dry rolled and high moisture corn were fed to multipa- } \\
\text { rous lactating Holstein cows in a } 4 \times 4 \text { Latin square } \\
\text { design. Samples of feed, orts, feces, and urine were col- } \\
\text { lected for the last } 4 \text { d of each period and composited on } \\
\text { a weight basis. } \\
\text { 3. Dietary treatments contained either control corn silage } \\
\text { or corn silage ensiled with inoculant fed to } 8 \text { multiparous } \\
\text { lactating Holstein cows (4 cows per treatment per pe- } \\
\text { riod) in a switchback design. Samples of feed, orts, feces, } \\
\text { and urine were collected for the last } 4 \mathrm{~d} \text { of each period } \\
\text { and composited on a weight basis. }\end{array}$ \\
\hline Pennsylvania State University & $\begin{array}{l}\text { Published experiments } \\
\text { Gabler and Heinrichs, 2003a } \\
\text { Gabler and Heinrichs, 2003b } \\
\text { Zanton et al., } 2003\end{array}$ \\
\hline The Ohio State University & $\begin{array}{l}\text { Published experiments } \\
\text { Weiss and Wyatt, } 2004\end{array}$ \\
\hline University of California, Davis & $\begin{array}{l}\text { Published experiments } \\
\text { James et al., } 1999 \\
\text { Meyer et al., } 2000\end{array}$ \\
\hline
\end{tabular}

Diets fed during the metabolism trials included a wide variety of protein supplements and forage types. Forages included corn silage, grass silage, alfalfa silage, and grass hay. The remainder of the diets included various grains, by-product feeds, and mineral supplements. Cows in these trials were fed ad libitum.

Equations given for each parameter include residual standard error (SE) and interstudy SE. Equations with lower SE are expected to provide a more precise estimation of excretion and should be used when values for the input variables are available.

\section{Sample Collection and Analyses}

Contemporary data available for use in our study were predominantly from lactating cows. Few scientists have completed total collection studies on dry cows, replacement heifers, or young calves. Total collection metabolism studies (16 studies) conducted at Washington State University included both lactating cows (399 cow-periods) and dry cows (7 cow-periods). Feeding, sample collection, and sample analyses were conducted by methods outlined by Johnson et al. (1998) and Timmermans et al. (2000). Metabolism studies from the University of California, Davis included 3 calf studies,
3 heifer studies, 2 dry cow studies, and 4 lactating cow studies. Feeding and sample collections were described by James et al. (1999) and Meyer et al. (2000). Methods used for collection during the metabolism studies (6 studies; 139 cows or cow-periods) with lactating multiparous Holstein cows at The Ohio State University were reviewed by Weiss and Wyatt (2004). Studies from The Pennsylvania State University that included 32 observations from weaned calves and 32 observations from heifers are summarized by Gabler and Heinrichs $(2003 a, b)$. Minerals in feces were analyzed by the University of Nebraska Soil and Plant Analytical Laboratory (Lincoln, NE) and urine minerals were analyzed by Dairyland Laboratories (Arcadia, WI).

Mineral analyses were not conducted on milk samples. Therefore, milk mineral contents were assumed equivalent to values outlined in the 2001 Dairy NRC. Milk $\mathrm{P}$ and $\mathrm{K}$ were estimated at 0.9 and $1.5 \mathrm{~g} / \mathrm{kg}$ of milk, respectively (NRC, 2001).

\section{Statistical Analyses}

Regression analyses were performed using PROC MIXED of SAS (SAS Institute, 1999) with the discrete effect of study included as a random variable (St-Pierre, 
Table 2. Animal and production characteristics for the data sets used for development of prediction equations.

\begin{tabular}{|c|c|c|c|c|c|}
\hline Data set ${ }^{1}$ & $\mathrm{n}$ & Mean & Minimum & Maximum & SD \\
\hline \multicolumn{6}{|l|}{ LACT } \\
\hline $\mathrm{BW}, \mathrm{kg}$ & 554 & 630 & 437 & 830 & 66.1 \\
\hline DIM & 552 & 172 & 13 & 563 & 91.9 \\
\hline Milk, kg/d & 553 & 31.4 & 1.4 & 86.1 & 11.0 \\
\hline $\mathrm{DMI}, \mathrm{kg} / \mathrm{d}$ & 553 & 21.7 & 6.8 & 32.9 & 3.9 \\
\hline Milk fat, g/g of milk & 554 & 0.0362 & 0.0225 & 0.0673 & 0.0067 \\
\hline Milk protein, $\mathrm{g} / \mathrm{g}$ of milk & 529 & 0.0299 & 0.0161 & 0.0447 & 0.0034 \\
\hline Dietary CP, g/g of DM & 529 & 0.175 & 0.124 & 0.244 & 0.0185 \\
\hline Dietary NDF, $\mathrm{g} / \mathrm{g}$ of DM & 554 & 0.364 & 0.265 & 0.454 & 0.0507 \\
\hline \multicolumn{6}{|l|}{ MINERAL } \\
\hline $\mathrm{BW}, \mathrm{kg}$ & 85 & 617 & 437 & 745 & 69.4 \\
\hline DIM & 85 & 165 & 27 & 356 & 80.2 \\
\hline Milk, kg/d & 85 & 31.5 & 6.0 & 44.3 & 7.8 \\
\hline DMI, $\mathrm{kg} / \mathrm{d}$ & 85 & 21.9 & 10.5 & 30.1 & 4.3 \\
\hline Milk fat, g/g of DM & 85 & 0.0355 & 0.0230 & 0.0550 & 0.0066 \\
\hline Milk protein, $\mathrm{g} / \mathrm{g}$ of $\mathrm{DM}$ & 85 & 0.0292 & 0.0218 & 0.0381 & 0.0030 \\
\hline Dietary $P, g / g$ of DM & 66 & 0.0044 & 0.0025 & 0.0060 & 0.0007 \\
\hline Dietary $\mathrm{K}, \mathrm{g} / \mathrm{g}$ of $\mathrm{DM}$ & 66 & 0.0129 & 0.0096 & 0.0176 & 0.0019 \\
\hline \multicolumn{6}{|l|}{ Early lactation cows } \\
\hline $\mathrm{BW}, \mathrm{kg}$ & 15 & 591 & 539 & 719 & 54.1 \\
\hline DIM & 15 & 38 & 16 & 61 & 15.6 \\
\hline Milk, kg/d & 15 & 66.5 & 48.2 & 86.1 & 9.6 \\
\hline DMI, kg/d & 15 & 18.2 & 13.3 & 21.4 & 2.1 \\
\hline Milk fat, g/g of DM & 15 & 0.0424 & 0.0270 & 0.0642 & 0.0112 \\
\hline Milk protein, g/g of DM & 15 & 0.0283 & 0.0252 & 0.0307 & 0.0017 \\
\hline Dietary P, g/g of DM & 15 & 0.0046 & 0.0043 & 0.0052 & 0.0002 \\
\hline Dietary K, g/g of DM & 15 & 0.0157 & 0.0146 & 0.0168 & 0.0064 \\
\hline \multicolumn{6}{|l|}{ DRY } \\
\hline BW, kg & 18 & 755 & 413 & 934 & 155.3 \\
\hline DMI, kg/d & 18 & 10.4 & 5.1 & 16.8 & 3.2 \\
\hline Dietary CP, g/g of DM & 18 & 0.133 & 0.080 & 0.230 & 0.061 \\
\hline Dietary NDF, g/g of DM & 11 & 0.466 & 0.350 & 0.579 & 0.094 \\
\hline \multicolumn{6}{|l|}{ HEIFER } \\
\hline $\mathrm{BW}, \mathrm{kg}$ & 60 & 437 & 274 & 613 & 65.4 \\
\hline DMI, kg/d & 60 & 8.34 & 6.23 & 10.66 & 1.12 \\
\hline Dietary CP, g/g of DM & 60 & 0.112 & 0.073 & 0.216 & 0.031 \\
\hline Dietary NDF, g/g of DM & 36 & 0.498 & 0.379 & 0.598 & 0.059 \\
\hline Dietary $\mathrm{P}, \mathrm{g} / \mathrm{g}$ of $\mathrm{DM}$ & 32 & 0.0029 & 0.0026 & 0.0035 & 0.0002 \\
\hline Dietary K, g/g of DM & 32 & 0.0147 & 0.0121 & 0.0178 & 0.0019 \\
\hline \multicolumn{6}{|l|}{ CALF } \\
\hline $\mathrm{BW}, \mathrm{kg}$ & 46 & 152.8 & 86.0 & 203.7 & 31.0 \\
\hline DMI, kg/d & 46 & 3.37 & 2.38 & 5.15 & 0.50 \\
\hline Dietary $\mathrm{CP}, \mathrm{g} / \mathrm{g}$ of $\mathrm{DM}$ & 46 & 0.166 & 0.092 & 0.227 & 0.024 \\
\hline Dietary NDF, g/g of DM & 44 & 0.395 & 0.299 & 0.512 & 0.055 \\
\hline Dietary $\mathrm{P}, \mathrm{g} / \mathrm{g}$ of $\mathrm{DM}$ & 32 & 0.0037 & 0.00032 & 0.0029 & 0.0042 \\
\hline
\end{tabular}

${ }^{1}$ Characteristics are included for data sets with all lactating cows (LACT), lactating cows for which mineral data was available (MINERAL), early lactation cows, dry cows (DRY), heifers (HEIFERS), and calves (CALF).

2001). Equations were developed by running multiple iterations in MIXED and removing the least significant effect at each iteration. For data sets equal to or greater than 200 observations, variables were kept if $P<0.10$. For data sets with less than 200 observations, variables were kept if $P<0.25$. Adjusted observations were calculated for graphing purposes by adding the residual from each individual observation to the predicted value of the study regression (St-Pierre, 2001).

Equation evaluation was done by regressing residuals (predicted values subtracted from observed values) on the predicted values (St-Pierre, 2003). Predicted values were centered by subtracting the mean of all pre- dicted values from each prediction. This makes the slope and intercept estimates in the regression orthogonal and, thus, independent. Mean biases were assessed using the intercepts of the regression equations, and the slopes of the regression equations were used to determine the presence of linear biases.

\section{RESULTS AND DISCUSSION}

\section{Lactating Cows}

Total manure excretion. Equations for $M_{E}$ were developed using the LACT data set (554 cow-periods). 
Table 3. Definitions of variables used in the prediction equations developed for the proposed revisions of the ASAE manure characteristics. Units are on a per animal basis.

\begin{tabular}{lll}
\hline Variable & Description & Units \\
\hline Animal performance characteristics & & \\
MILK & Milk yield & $\mathrm{kg}$ of milk/d \\
MF & Milk fat & g of fat/g of milk \\
MTP & Milk true protein & $\mathrm{g}$ of protein/g of milk \\
MilkP & Milk P & $\mathrm{g}$ of P/g of milk \\
DIM & Days in milk & $\mathrm{d}$ \\
BW & Body weight & $\mathrm{kg}$ \\
Dietary characteristics & & \\
DMI & Dry matter intake & $\mathrm{kg}$ of DM/d \\
DMD & Apparent DM digestibility of total ration & $\mathrm{g} / \mathrm{g}$ of DM \\
Excretion $_{\mathrm{M}_{\mathrm{E}}}$ & & $\mathrm{kg} / \mathrm{d}$ \\
$\mathrm{N}_{\mathrm{E}}$ & Total manure excretion & $\mathrm{g} / \mathrm{d}$ \\
$\mathrm{P}_{\mathrm{E}}$ & Total N excretion & $\mathrm{g} / \mathrm{d}$ \\
$\mathrm{K}_{\mathrm{E}}$ & Total P excretion & $\mathrm{g} / \mathrm{d}$ \\
$\mathrm{DM}_{\mathrm{E}}$ & Total K excretion & $\mathrm{kg} / \mathrm{d}$ \\
\hline
\end{tabular}

Manure excretion for cows in this data set averaged $66.3 \mathrm{~kg} / \mathrm{d}$ for cows with an average BW of $630 \mathrm{~kg}$ and a DMI of $21.7 \mathrm{~kg} / \mathrm{d}$. In comparison, Wilkerson et al. (1997) reported cows with an average milk yield of 29 $\mathrm{kg} / \mathrm{d}$ excreted $89 \mathrm{~kg}$ of manure/d per $1000 \mathrm{~kg}$ of BW, which is equivalent to $56.1 \mathrm{~kg}$ of $\mathrm{M}_{\mathrm{E}} / \mathrm{d}$ from a 630 $\mathrm{kg}$ cow averaging $17.9 \mathrm{~kg}$ of DMI/d. Average $\mathrm{M}_{\mathrm{E}}$ for lactating cows in the LACT data set was $8.2 \mathrm{~kg}$ greater than for cows in the study by Wilkerson et al. (1997). Frank et al. (2002) reported $\mathrm{M}_{\mathrm{E}}$ ranging from 44.9 to $49.1 \mathrm{~kg} / \mathrm{d}$ for cows consuming between 18.3 and $20.2 \mathrm{~kg}$ of $\mathrm{DM} / \mathrm{d}$, excretion values even lower than from Wilkerson et al. (1997).

The historic ASAE (2001) table listed excretion values on a basis of $1000 \mathrm{~kg}$ of BW. The newly adopted table values (Table 4), based on prediction equations described in the following narrative, provide excretion estimates on a per-animal basis and include descriptions of animals and dietary assumptions used to develop the values. Table values, common in historic ASAE standards, were generated with corresponding nutritional parameters to provide an average value for predicting manure excretion. In addition, prediction equations were developed for each of the excretion parameters when enough data were present. The goal of including the prediction equations was to provide excretion estimates that are adaptable to particular operations in lieu of a general table value that is used by all dairy operations, regardless of the production level, breed, or size of the animals.

A simple equation with MILK as the only input variable was developed to provide a practical equation for use when other animal factors are not known or the individuals providing technical assistance are not familiar with dietary information. An equation using
MILK as the only variable was included to provide nutrient management planners with a more precise alternative to the use of the general table value.

$$
\begin{gathered}
\mathrm{M}_{\mathrm{E}}=[\mathrm{MILK} \times 0.616( \pm 0.057)]+46.2( \pm 2.3) \\
\text { Residual } \mathrm{SE}=10.0 ; \text { interstudy } \mathrm{SE}=7.1
\end{gathered}
$$

The simple equation with MILK provides flexibility not previously given in the ASAE standards. The ASAE (2001) value for $M_{E}$ was listed as $86 \mathrm{~kg} / \mathrm{d}$ per $1000 \mathrm{~kg}$ of BW (54.2 kg/d for a 630-kg cow). Using equation [1], $\mathrm{M}_{\mathrm{E}}$ would average 58.5 and $70.8 \mathrm{~kg} / \mathrm{d}$ for cows producing 15 and $40 \mathrm{~kg} / \mathrm{d}$, respectively. The lower $\mathrm{M}_{\mathrm{E}}$ estimates given in the $2001 \mathrm{ASAE}$ tables are a result of lower milk production and DMI of cows used to generate those values.

Body weight was a predictor of $\mathrm{M}_{\mathrm{E}}(P<0.01)$, and similar findings were reported in equations developed by Wilkerson et al. (1997). When comparisons were made between equations including either MILK or BW, equations with MILK improved the prediction across studies by $18 \%$ when predicting $\mathrm{M}_{\mathrm{E}}$. The less accurate relationship of $\mathrm{BW}$ to $\mathrm{M}_{\mathrm{E}}$ in the prediction equations indicated that basing $\mathrm{M}_{\mathrm{E}}$ on BW, as was done in 2001 ASAE, is not the most accurate method of predicting $\mathrm{M}_{\mathrm{E}}$ from lactating cows.

Inclusion of DMI in equation [2] provided a more precise estimation of $\mathrm{M}_{\mathrm{E}}$ than equations that did not include DMI. The best single independent variable for predicting $\mathrm{M}_{\mathrm{E}}$ in the LACT data set was DMI [2].

$$
\begin{aligned}
& \mathrm{M}_{\mathrm{E}}=[\mathrm{DMI} \times 2.63( \pm 0.10)]+9.4( \pm 2.8) \\
& \text { Residual SE }=7.1 ; \text { interstudy } \mathrm{SE}=9.5
\end{aligned}
$$


Table 4. Estimated typical manure (urine and feces combined) characteristics as excreted ${ }^{1}$ by dairy animals.

\begin{tabular}{llllll}
\hline $\begin{array}{l}\text { Animal type } \\
\text { and production } \\
\text { grouping }\end{array}$ & $\begin{array}{l}\text { Total } \\
\text { manure }\end{array}$ & $\begin{array}{l}\text { Total } \\
\text { DM }\end{array}$ & $\mathrm{N}$ & $\mathrm{P}$ & $\mathrm{K}$ \\
\hline & & & $\mathrm{kg} / \mathrm{d}$ & & \\
\hline & & & 0.491 & 0.074 & 0.223 \\
Lactating cow $^{2}$ & 75.2 & 9.7 & 0.228 & $\mathrm{NA}^{6}$ & $\mathrm{NA}$ \\
Dry cow $^{3}$ & 38.6 & 4.5 & 0.117 & 0.020 & $\mathrm{NA}$ \\
Heifer $^{4}$ & 24.5 & 3.74 & 0.063 & 0.008 & NA \\
Calf $^{5}$ & 12.4 & 1.37 & 0.281 & 0.059 & 0.181 \\
$2001 \mathrm{ASAE}^{7}$ & 53.8 & $\mathrm{NA}$ & 0.28 & \\
\hline
\end{tabular}

${ }^{1}$ Prior to any changes due to dilution water addition, drying, volatilization or other physical, chemical or biological processes.

${ }^{2}$ Lactating cow excretion estimates are based on a $625-\mathrm{kg}$ cow producing $40 \mathrm{~kg}$ of milk per day with intakes of $25 \mathrm{~kg}$ of DM, $4.38 \mathrm{~kg}$ of CP, $0.095 \mathrm{~kg}$ of P, and $0.325 \mathrm{~kg}$ of $\mathrm{K}$ per day.

${ }^{3}$ Dry cow excretion estimates based on a $755-\mathrm{kg}$ cow with intakes of $10.4 \mathrm{~kg}$ of DM and $1.38 \mathrm{~kg}$ of $\mathrm{N}$ per day.

${ }^{4}$ Heifer excretion estimates are based on a $437-\mathrm{kg}$ heifer with intakes of $8.3 \mathrm{~kg}$ of DM, $0.93 \mathrm{~kg}$ of $\mathrm{CP}$, and $0.024 \mathrm{~kg}$ of $\mathrm{P}$ per day.

${ }^{5}$ Calf excretion estimates are based on a $153-\mathrm{kg}$ calf with intakes of $3.4 \mathrm{~kg}$ of DM, $0.56 \mathrm{~kg}$ of CP and 0.013 $\mathrm{kg}$ of $\mathrm{P}$ per day.

${ }^{6} \mathrm{NA}=$ Data not available.

${ }^{7} \mathrm{ASAE}$ values are based on a $625-\mathrm{kg}$ animal.

Figure 1 shows the relationship between DMI and $\mathrm{M}_{\mathrm{E}}$. Including DMI as an independent variable improved the precision of the estimation by reducing the residual SE by $28.9 \%$ as compared with using MILK. Inclusion of DMI in the equations has become a more realistic option as producers have improved recordkeeping skills and increased the use of scales.

Dietary NDF concentration was evaluated in the LACT data set to determine if it was a significant factor

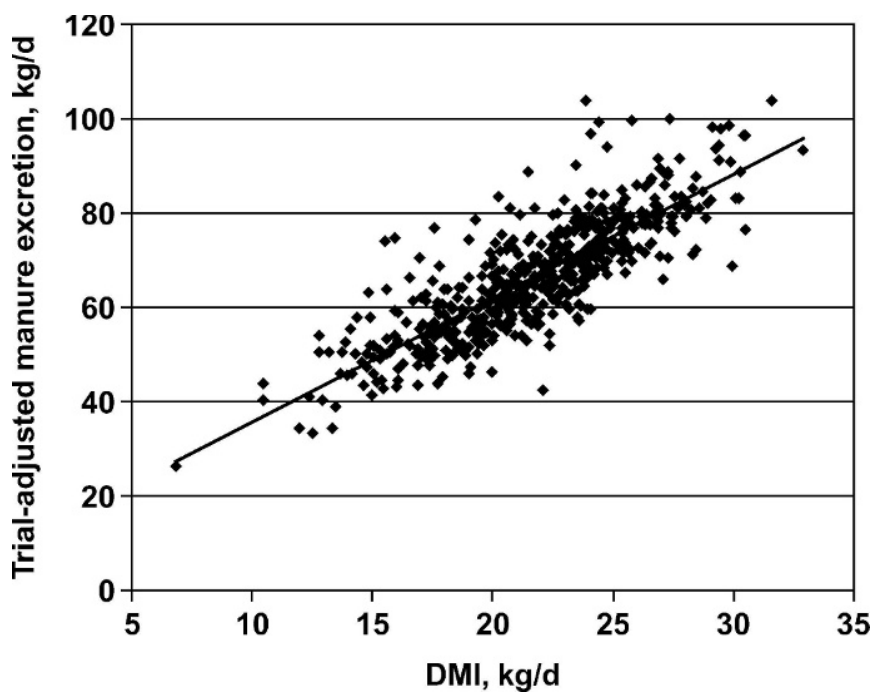

Figure 1. Relationship between DM intake and trial-adjusted manure excretion for lactating cows (554 cow-periods). The solid line is equal to manure excretion, $\mathrm{kg} / \mathrm{d}=(\mathrm{DMI}, \mathrm{kg} / \mathrm{d} \times 2.63)+9.4 ;$ Residual $\mathrm{SE}=7.1$, interstudy $\mathrm{SE}=9.5$. for predicting $\mathrm{M}_{\mathrm{E}}$ as indicated by Wilkerson et al. (1997). When dietary NDF concentration was evaluated in the LACT data set, it was positively related to $\mathrm{M}_{\mathrm{E}}$ regardless of the inclusion of DMI in the regression models. Crude protein intake was also positively related to $\mathrm{M}_{\mathrm{E}}$, indicating that the total amount of $\mathrm{CP}$ consumed affected $\mathrm{M}_{\mathrm{E}}$. Similarly, Frank et al. (2002) reported an increase in $\mathrm{M}_{\mathrm{E}}$ as greater amounts of $\mathrm{CP}$ were fed.

Most of the nonlinear models evaluated resulted in prediction equations that were less accurate predictors of $\mathrm{M}_{\mathrm{E}}$ than linear equations. The best nonlinear equation for describing the LACT data set included several of the same independent variables given by Wilkerson et al. (1997) (BW, DMI, DIM, dietary CP, and dietary $\mathrm{NDF}$ ) and included the interaction of DMI and dietary CP as well as squared terms of DIM and dietary NDF. The nonlinear equation improved the residual SE of equation [2] by only $1 \%$. Because the nonlinear equations provided only a very slight improvement over the linear equations, we suggest the use of the linear equations for predicting $\mathrm{M}_{\mathrm{E}}$.

In addition to the development of new prediction equations using the LACT data set, previously published equations for predicting $\mathrm{M}_{\mathrm{E}}$ were evaluated. Predictions using the equation of Wilkerson et al. (1997) $\left[\mathrm{M}_{\mathrm{E}}=(0.0286 \times \mathrm{BW})+(0.0378 \times \mathrm{DIM})+(1.0689 \times\right.$ MILK $)+(9.67 \times$ Dietary CP, g/g of DM $)+(61.4 \times$ Dietary $\mathrm{NDF}, \mathrm{g} / \mathrm{g}$ of DM) - 21.94] resulted in mean and linear biases $(P<0.01)$ of $5.6 \mathrm{~kg} / \mathrm{d}$ and -0.25 , respectively. Although $\mathrm{M}_{\mathrm{E}}$ in the LACT data set was greater than that predicted using the Wilkerson et al. (1997) equa- 
Table 5. Average excretion values ( $\mathrm{kg} / \mathrm{d}$ ) for animals in the data sets of lactating cows (LACT), lactating cows for which mineral data was available (MINERAL), early lactation cows, dry cows (DRY), heifers (HEIFERS), and calves (CALF).

\begin{tabular}{|c|c|c|c|c|c|}
\hline Data set & $\mathrm{n}$ & Mean & Minimum & Maximum & SD \\
\hline \multicolumn{6}{|l|}{ LACT } \\
\hline Manure & 554 & 66.3 & 27.7 & 114.4 & 14.4 \\
\hline Total DM & 538 & 8.52 & 3.22 & 14.78 & 1.80 \\
\hline Fecal DM & 538 & 7.25 & 1.74 & 12.93 & 1.63 \\
\hline Urine & 554 & 23.1 & 8.4 & 58.7 & 7.19 \\
\hline Nitrogen & 529 & 0.4387 & 0.180 & 0.741 & 0.0943 \\
\hline Fecal N & 530 & 0.2223 & 0.0723 & 0.4419 & 0.591 \\
\hline Urinary N & 529 & 0.2165 & 0.0630 & 0.4986 & 0.0643 \\
\hline \multicolumn{6}{|l|}{ MINERAL } \\
\hline Manure & 85 & 67.4 & 34.5 & 100.8 & 13.4 \\
\hline Total P & 85 & 0.0739 & 0.0274 & 0.1145 & 0.0162 \\
\hline Total K & 85 & 0.2003 & 0.0920 & 0.3488 & 0.0487 \\
\hline Urinary $\mathrm{K}$ & 85 & 0.1505 & 0.0538 & 0.3056 & 0.0450 \\
\hline \multicolumn{6}{|c|}{ Early lactation cows } \\
\hline Manure & 15 & 97.1 & 73.6 & 114.4 & 12.7 \\
\hline Nitrogen & 15 & 0.5732 & 0.4232 & 0.6984 & 0.0772 \\
\hline Total P & 15 & 0.1054 & 0.0714 & 0.1452 & 0.0180 \\
\hline Total K & 15 & 0.3434 & 0.1774 & 0.4684 & 0.0824 \\
\hline \multicolumn{6}{|l|}{ DRY } \\
\hline Manure & 18 & 38.6 & 22.2 & 54.8 & 8.9 \\
\hline Total DM & 18 & 4.54 & 2.49 & 5.84 & 0.92 \\
\hline Urine & 18 & 15.4 & 8.4 & 32.1 & 6.3 \\
\hline Nitrogen & 18 & 0.2284 & 0.0800 & 0.5033 & 0.1366 \\
\hline Fecal N & 18 & 0.0901 & 0.0300 & 0.2033 & 0.0538 \\
\hline Urinary N & 18 & 0.1383 & 0.0400 & 0.3300 & 0.0897 \\
\hline \multicolumn{6}{|l|}{ HEIFERS } \\
\hline Manure & 60 & 24.5 & 18.1 & 40.3 & 4.8 \\
\hline Total DM & 32 & 3.74 & 3.18 & 4.47 & 0.32 \\
\hline Urine & 60 & 9.0 & 6.3 & 18.7 & 3.0 \\
\hline Nitrogen & 60 & 0.1173 & 0.0700 & 0.2200 & 0.0317 \\
\hline Fecal N & 60 & 0.0577 & 0.0300 & 0.0800 & 0.0012 \\
\hline Urinary $\mathrm{N}$ & 60 & 0.0597 & 0.0300 & 0.1600 & 0.0305 \\
\hline $\mathrm{P}$ & 32 & 0.0204 & 0.01873 & 0.02214 & 0.00113 \\
\hline \multicolumn{6}{|l|}{ CALF } \\
\hline Manure, & 46 & 12.4 & 5.0 & 28.8 & 6.4 \\
\hline Total DM & 46 & 1.37 & 0.66 & 2.54 & 0.47 \\
\hline Nitrogen & 46 & 0.0628 & 0.0335 & 0.1100 & 0.0146 \\
\hline Fecal N & 46 & 0.0236 & 0.0100 & 0.0400 & 0.0058 \\
\hline Urinary $\mathrm{N}$ & 46 & 0.0393 & 0.0185 & 0.0738 & 0.0123 \\
\hline $\mathrm{P}$ & 32 & 0.0078 & 0.0050 & 0.0126 & 0.0017 \\
\hline
\end{tabular}

tion, the difference was less than the standard deviation of the residuals. The comparison of previous equations with the LACT data set provides an evaluation of those equations using this data set. An independent data set would be required to compare the accuracy of previous and new equations.

DM excretion. The average fecal DM excretion was $7.3 \mathrm{~kg} / \mathrm{d}$ and $\mathrm{DM}_{\mathrm{E}}$ was $8.5 \mathrm{~kg} / \mathrm{d}$ (Table 5). Tomlinson et al. (1996) reported fecal DM excretion ranging from 6.2 to $7.4 \mathrm{~kg} / \mathrm{d}$, values similar to those in the LACT data set. The best predictor of $\mathrm{DM}_{\mathrm{E}}$ was DMI [3].

$$
\begin{gathered}
\mathrm{DM}_{\mathrm{E}}=[\mathrm{DMI} \times 0.356( \pm 0.011)]+0.80( \pm 0.34) \quad[3] \\
\text { Residual SE }=0.78 ; \text { interstudy } \mathrm{SE}=1.11
\end{gathered}
$$

Equation [3] indicated a direct relationship between $\mathrm{DMI}$ and $\mathrm{DM}_{\mathrm{E}}$. In 1994, Van Horn et al. reported that
$\mathrm{DM}_{\mathrm{E}}$ could be determined by multiplying DMI by 0.33 and adding the urine DM.

Other variables evaluated for predicting $\mathrm{DM}_{\mathrm{E}}$ were BW, DIM, MILK, MF, and MTP, but these variables were not significant $(P>0.25)$ when included in the equation with DMI. Conversely, dietary NDF concentration was a significant variable $(P<0.01)$ when included in an equation with DMI, but resulted in a less precise prediction equation across studies than when DMI was the only independent variable for predicting $\mathrm{DM}_{\mathrm{E}}$.

Two equations were developed for predicting $\mathrm{DM}_{\mathrm{E}}$ in the absence of DMI:

$$
\begin{gathered}
\mathrm{DM}_{\mathrm{E}}=[\mathrm{MILK} \times 0.0874( \pm 0.0070)]+5.6( \pm 0.30)[4] \\
\text { Residual SE }=1.21 ; \text { interstudy } \mathrm{SE}=0.87
\end{gathered}
$$




$$
\begin{gathered}
\mathrm{DM}_{\mathrm{E}}=[\mathrm{MILK} \times 0.112( \pm 0.008)] \\
+[\mathrm{BW} \times 0.0062( \pm 0.00089)]+ \\
{[\mathrm{MTP} \times 106.0( \pm 18.8)]-2.2( \pm 0.95)}
\end{gathered}
$$

Residual $\mathrm{SE}=1.15$; interstudy $\mathrm{SE}=0.78$

Equation [4] provides a prediction of $\mathrm{DM}_{\mathrm{E}}$ based solely on MILK, and equation [5] includes BW, MTP, and MILK. Predictions of $\mathrm{DM}_{\mathrm{E}}$ using equations [4] and [5] are expected to be less accurate than predictions using equation [3], but provide estimates in instances where DMI is not known.

Nitrogen excretion. The simple linear equation, using MILK as the only independent variable [6], indicated a positive relationship $(P<0.01)$ between $\mathrm{N}_{\mathrm{E}}$ and MILK. When MILK was used as the only prediction variable, it resulted in a less precise prediction than subsequent equations evaluated, but using MILK as the only variable resulted in a $2.6 \%$ improvement in accuracy compared with use of $\mathrm{BW}$ to predict $\mathrm{N}_{\mathrm{E}}$.

$$
\begin{gathered}
\mathrm{N}_{\mathrm{E}}=[\mathrm{MILK} \times 2.82( \pm 0.42)]+346( \pm 18.1) \\
\text { Residual SE }=70.9 ; \text { interstudy } \mathrm{SE}=57.9
\end{gathered}
$$

Equations were also developed for situations where intake of CP is known. When evaluated in a simple equation, $\mathrm{CP}$ intake was positively related $(P<0.01)$ to $\mathrm{N}_{\mathrm{E}}$ [7].

$$
\begin{aligned}
\mathrm{N}_{\mathrm{E}}=[\mathrm{DMI} \times & \text { Dietary CP }, \mathrm{g} / \mathrm{g} \text { of } \mathrm{DM} \times 84.1( \pm 3.7)] \\
& +[\mathrm{BW} \times 0.196( \pm 0.026)]
\end{aligned}
$$

Residual $\mathrm{SE}=51.4$; interstudy $\mathrm{SE}=56.1$

As expected, an increase in $\mathrm{CP}$ consumption resulted in greater $\mathrm{N}_{\mathrm{E}}$. The most precise equation developed for predicting $\mathrm{N}_{\mathrm{E}}$ included $\mathrm{CP}$ intake as an independent variable [7]. Equation [7] improved the residual SE by $27.5 \%$ compared with equation [6]. The direct relationship between $\mathrm{N}$ intake and $\mathrm{N}_{\mathrm{E}}$ indicates that future improvements in balancing diets to better meet the specific amino acid needs of the animal while decreasing dietary $\mathrm{CP}$ concentrations may be an important step in decreasing $\mathrm{N}_{\mathrm{E}}$ (Harrison et al., 2002).

Nitrogen intake was directly related to $\mathrm{N}_{\mathrm{E}}$ in previous experiments (Tomlinson et al., 1996; James et al., 1999; Krober et al., 2000; Frank et al., 2002). Excess intake $\mathrm{N}$ is mostly excreted via urinary excretion. Tomlinson et al. (1996) indicated that $\mathrm{N}_{\mathrm{E}}$ was closely related to $\mathrm{N}$ intake and DMI and somewhat related to BW, whereas Van Horn et al. (1994) stated that $\mathrm{N}_{\mathrm{E}}$ could be estimated by subtracting the $\mathrm{N}$ in milk from $\mathrm{N}$ intake.
Quadratic models were evaluated to determine if the predictions were improved with the addition of squared terms and interactions in the model. When quadratic models were evaluated, the resulting equations did not reduce the residual SE or interstudy SE compared with the linear models. Conversely, Wilkerson et al. (1997) reported that development of quadratic models led to a statistical improvement over the linear models developed for predicting $\mathrm{N}_{\mathrm{E}}$. These authors, however, did not account for the imbalance of the predictor variables across studies (the random study effect in the model) and thus, might have induced the apparent nonlinearity of the prediction.

Previously published equations for predicting $\mathrm{N}_{\mathrm{E}}$ (Wilkerson et al., 1997) were evaluated using the LACT data set. Evaluation of the linear equation published by Wilkerson et al. in $1997\left[\mathrm{~N}_{\mathrm{E}}=(0.000232 \times \mathrm{BW})+\right.$ $(0.000342 \times \mathrm{DIM})+(0.00649 \times \mathrm{MILK})+(1.83 \times$ Dietary $\mathrm{CP}, \mathrm{g} / \mathrm{g}$ of $\mathrm{DM})+(0.280 \times$ Dietary NDF, g/g of DM $)-$ $0.440]$ resulted in a mean bias of $37.4 \mathrm{~g} / \mathrm{d}(P<0.01)$ of excreted $\mathrm{N}$ and a linear bias of $-0.264(P<0.01)$. The standard deviation of the residuals of the LACT data set was $0.0784 \mathrm{~kg} / \mathrm{d}$, indicating that the mean bias was less than the variation expected between studies.

Phosphorus excretion. Dietary $\mathrm{P}$ concentrations in the MINERAL data set averaged $0.0044 \mathrm{~g} / \mathrm{g}$ of DM. Many of the studies in the MINERAL data set were conducted before reduced $\mathrm{P}$ feeding was emphasized in dairy diets, which resulted in dietary $\mathrm{P}$ concentrations greater than needed to meet animal requirements. Because cows were fed diets with $\mathrm{P}$ concentrations greater than their requirements, equations developed with the MINERAL data set may not accurately account for diets with $\mathrm{P}$ supply at or below animal requirements.

The 2001 ASAE estimate of $\mathrm{P}_{\mathrm{E}}$ for a $630-\mathrm{kg}$ cow was $0.0592 \mathrm{~kg} / \mathrm{d}, 0.0147 \mathrm{~kg} / \mathrm{d}$ less than the average $\mathrm{P}_{\mathrm{E}}$ for cows in the MINERAL data set (Table 5). In contrast, an average $P_{E}$ of $0.057 \mathrm{~kg} / \mathrm{d}$ was reported by Weiss and Wyatt (2004), which was similar to the $2001 \mathrm{ASAE}$ value. However, the $\mathrm{P}$ intake in the MINERAL data set averaged $0.013 \mathrm{~kg} / \mathrm{d}$ more than the cows in the Weiss and Wyatt (2004) study, and would account for most of the difference in $\mathrm{P}_{\mathrm{E}}$.

The simple equation [8] developed using MILK as the only predictor of $\mathrm{P}_{\mathrm{E}}$ indicated a positive relationship between MILK and $\mathrm{P}_{\mathrm{E}}$.

$$
\begin{gathered}
\mathrm{P}_{\mathrm{E}}=[\mathrm{MILK} \times 0.781( \pm 0.230)]+50.4( \pm 8.6) \\
\text { Residual SE }=13.4 ; \text { interstudy } \mathrm{SE}=11.3
\end{gathered}
$$

The positive relationship between MILK and $\mathrm{P}_{\mathrm{E}}$ is most likely a result of greater intakes of high-producing cows. Although MILK may be used for predicting $\mathrm{P}_{\mathrm{E}}$, 


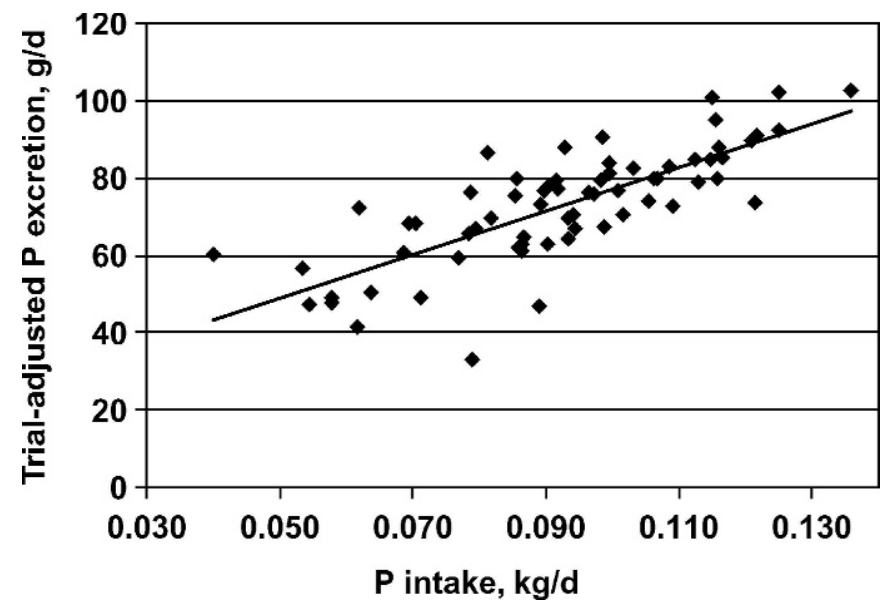

Figure 2. Relationship between $\mathrm{P}$ intake and trial-adjusted $\mathrm{P}$ excretion for lactating cows (66 cow-periods). The solid line is equal to $\mathrm{P}$ excretion, $\mathrm{g} / \mathrm{d}=(\mathrm{P}$ intake, $\mathrm{kg} / \mathrm{d} \times 560.7)+21.1 ;$ Residual $\mathrm{SE}=$ 9.7, interstudy $\mathrm{SE}=9.2$.

accuracy of predictions increased when $\mathrm{P}$ intake was included in the equations. Development of a simple equation with $\mathrm{P}$ intake as the only predictor reduced the residual SE by $16 \%$ [9].

$$
\begin{gathered}
\mathrm{P}_{\mathrm{E}}=[\mathrm{DMI} \times \text { Dietary } \mathrm{P}, \mathrm{g} / \mathrm{g} \text { of } \mathrm{DM} \times 560.7( \pm 71.1)] \\
+21.1( \pm 7.7)
\end{gathered}
$$$$
\text { Residual } \mathrm{SE}=9.7 \text {; interstudy } \mathrm{SE}=9.2
$$

In this data set, $\mathrm{P}$ intake was the best single independent variable for predicting $\mathrm{P}_{\mathrm{E}}$ (Figure 2). Similarly, Beede and Davidson (1999) and Weiss and Wyatt (2004) found that $\mathrm{P}$ intake was the most important single factor in determining $\mathrm{P}_{\mathrm{E}}$. When an additional equation that included MILK and MTP was developed for predicting $\mathrm{P}_{\mathrm{E}}$, there was a reduction in the residual $\mathrm{SE}$ from 9.7 to 9.3. However, the precision of future predictions across studies was not improved with the addition of MILK and MTP to the equation.

Other researchers have proposed equations for the prediction of $\mathrm{P}_{\mathrm{E}}$ (Van Horn et al., 1994; Beede and Davidson, 1999; Weiss and Wyatt, 2004). Beede and Davidson (1999) evaluated several $\mathrm{P}_{\mathrm{E}}$ equations and determined that prediction of $\mathrm{P}_{\mathrm{E}}$ was most accurately estimated using [10].

$$
\begin{gathered}
\mathrm{P}_{\mathrm{E}}=(\mathrm{DMI} \times \text { Dietary } \mathrm{P}, \mathrm{g} / \mathrm{g} \text { of } \mathrm{DM} \times 1000) \\
-(\mathrm{MilkP} \times 1000)
\end{gathered}
$$

Subtracting MilkP from $\mathrm{P}$ intake to estimate $\mathrm{P}_{\mathrm{E}}$ assumes there is no tissue mobilization or retention. In the MINERAL data set, evaluation of [10] resulted in a linear bias $(-0.409, P<0.01)$, but no mean bias $(P>$ 0.22). In 2004, Weiss and Wyatt proposed using [11] to estimate $\mathrm{P}_{\mathrm{E}}$.

$$
\begin{aligned}
\mathrm{P}_{\mathrm{E}} & =7.5+[(\mathrm{DMI} \times \text { Dietary } \mathrm{P}, \mathrm{g} / \mathrm{g} \text { of } \mathrm{DM} \\
& \times 1000) \times 0.78]-(\mathrm{MILK} \times 0.702)
\end{aligned}
$$

Evaluation of equation [11] indicated a mean bias $(0.0155 \mathrm{~kg} / \mathrm{d}, P<0.02)$ but no linear bias $(P>0.26)$ when evaluated using the MINERAL data set. The standard deviation of the residuals for the MINERAL data set was $0.0132 \mathrm{~kg} / \mathrm{d}$.

Potassium excretion. Potassium excretion occurs mainly in urine, with some unabsorbed $\mathrm{K}$ excreted in feces (NRC, 2001). Total $\mathrm{K}_{\mathrm{E}}$ in the MINERAL data set averaged $0.200 \mathrm{~kg} / \mathrm{d}$ with urinary $\mathrm{K}$ excretion accounting for approximately $75 \%$ of $\mathrm{K}_{\mathrm{E}}$. The $2001 \mathrm{ASAE}$ standards estimated $\mathrm{K}_{\mathrm{E}}$ to be $0.01827 \mathrm{~kg} / \mathrm{d}$.

Potassium excretion was directly related to both MILK [12] and dietary K concentration [13]. When MILK was evaluated as the only factor to predict $\mathrm{K}_{\mathrm{E}}$, a positive relationship between MILK and $\mathrm{K}_{\mathrm{E}}$ was found.

$$
\begin{aligned}
\mathrm{K}_{\mathrm{E}}= & {[\mathrm{MILK} \times 1.476( \pm 0.7207)]+154.1( \pm 24.5) } \\
& \text { Residual } \mathrm{SE}=43.2 ; \text { interstudy } \mathrm{SE}=23.6
\end{aligned}
$$

Milk production has been reported to have a curvilinear relationship to $\mathrm{K}$ intake, with the peak milk yield occurring at a dietary $\mathrm{K}$ concentration of $0.015 \mathrm{~g} / \mathrm{g}$ of DM (NRC, 2001). Conversely, inclusion of squared terms and interactions did not improve the models for predicting $\mathrm{K}_{\mathrm{E}}$ in the MINERAL data set. The lack of a curvilinear relationship in our data set was most likely due to the low dietary $\mathrm{K}$ concentrations in the MINERAL data set $(0.0129 \mathrm{~g} / \mathrm{g})$.

Future prediction of $\mathrm{K}_{\mathrm{E}}$ is expected to be more accurate if dietary $\mathrm{K}$ concentrations or $\mathrm{K}$ intakes are used to predict excretion. The best equation for prediction of $\mathrm{K}_{\mathrm{E}}$ included DMI and dietary $\mathrm{K}$ [13].

$$
\begin{aligned}
\mathrm{K}_{\mathrm{E}}=[\mathrm{DMI} \times 7.21( \pm 1.150)]+[\text { Dietary } \mathrm{K}, \mathrm{g} / \mathrm{g} \text { of } \mathrm{DM} \\
\times 15944( \pm 2691.2)]-164.5( \pm 50.6)
\end{aligned}
$$

$$
\text { Residual } \mathrm{SE}=36.9 \text {; interstudy } \mathrm{SE}=2.7
$$

When DMI and dietary $\mathrm{K}$ concentration were included in the equation, the SE between the studies in the data set was very small compared with equations that included other variables for predicting $\mathrm{K}_{\mathrm{E}}$.

Nutrient excretion in early lactation cows. Cows (15 cow-periods) from an early lactation study (average of 38 DIM) were evaluated separately due to the negative balances of $\mathrm{N}, \mathrm{P}$, and $\mathrm{K}$ for these cows. The average 
$\mathrm{N}$ balance for the early lactation cows was $-0.437 \mathrm{~kg} /$ $\mathrm{d}$. When the early lactation cows were evaluated using [7], the cows were excreting an average of $0.203 \mathrm{~kg} / \mathrm{d}$ more $\mathrm{N}$ then predicted by equation [7]. However, evaluation of these cows with equation [6], in which MILK as the only independent variable, only underestimated $\mathrm{N}$ excretion for the early lactation cows by an average of $0.040 \mathrm{~kg} / \mathrm{d}$.

The early lactation cows were not included in the MINERAL data set because of the greater excretion of $\mathrm{P}$ and $\mathrm{K}$ for the early lactation animals compared with cows in later lactation. For early lactation cows, $\mathrm{P}$ intake was not a significant factor $(P>0.25)$ to predict $\mathrm{P}_{\mathrm{E}}$, and $\mathrm{P}_{\mathrm{E}}$ was not related to $\mathrm{MILK}(P>0.25)$, DMI $(P$ $>0.25)$, or Ca intake $(P>0.16)$. Phosphorus excretion of these cows averaged over $0.023 \mathrm{~kg} / \mathrm{d}$ more than would be expected based on P intake and MILK. The greater $\mathrm{P}_{\mathrm{E}}$ for these early lactation animals is most likely a result of greater endogenous fecal $\mathrm{P}$ losses, possibly related to bone mobilization.

Potassium excretion of cows in the early lactation data set was greater than $\mathrm{K}_{\mathrm{E}}$ of cows in the MINERAL data set. On average, $\mathrm{K}_{\mathrm{E}}$ for early lactation cows was $0.143 \mathrm{~kg} / \mathrm{d}$ greater than cows in the MINERAL data set, even though K intakes were only $0.008 \mathrm{~kg} / \mathrm{d}$ greater (Table 2). Due to the greater $\mathrm{K}_{\mathrm{E}}$ and the greater secretion of $\mathrm{K}$ in milk, early lactation cows were in negative K balance. Silanikove et al. (1997) found that cows in early lactation are often in negative $\mathrm{K}$ balance and suggested that increased amounts of $\mathrm{K}$ in the diet may be beneficial to milk production.

\section{Dry Cows}

The DRY data set was a small data set and consisted of 18 cows. Of these dry cows, 15 cows were fed diets specifically formulated for dry cows and 3 cows were fed diets formulated for lactating cows. Due to the limited data set, prediction equations were not developed for dry cows and only average intake and excretion values are reported.

Manure excretion from dry cows averaged $38.6 \mathrm{~kg} / \mathrm{d}$ (Table 5), which was $12.3 \mathrm{~kg} / \mathrm{d}$ more than reported by Wilkerson et al. (1997), but similar to the $36.3 \mathrm{~kg} / \mathrm{d}$ estimate by Van Horn et al. (1994). The lower $\mathrm{M}_{\mathrm{E}}$ values from Wilkerson et al. (1997) are most likely a result of the restricted intakes for dry cows in their studies. The $\mathrm{DM}_{\mathrm{E}}$ estimate of $4.5 \mathrm{~kg} / \mathrm{d}$ for dry cows reported by Van Horn et al. (1994) was the same as the average value in the DRY data set.

Manure excretion for the DRY data set was $59 \%$ of the $2001 \mathrm{ASAE}$ value for $\mathrm{M}_{\mathrm{E}}$ for a cow weighing 755 $\mathrm{kg}$. However, the $2001 \mathrm{ASAE}$ values do not differentiate between lactating and nonlactating animals.
Mean $\mathrm{N}_{\mathrm{E}}$ from dry cows was $0.228 \mathrm{~kg} / \mathrm{d}$, though the range in $\mathrm{N}_{\mathrm{E}}$ was large (Table 5), and was $0.049 \mathrm{~kg} / \mathrm{d}$ greater than that reported by Wilkerson et al. (1997). Estimates of $\mathrm{N}_{\mathrm{E}}$ in the $2001 \mathrm{ASAE}$ standards were 0.340 $\mathrm{kg} / \mathrm{d}$ for dairy cattle and $0.257 \mathrm{~kg} / \mathrm{d}$ for beef cattle. Clearly, estimates for dry cows are closer to the 2001 ASAE estimates for beef cattle than for dairy cattle. Addition of dry cows to the updated standards will be an improvement over ASAE 2001 values and will improve the flexibility and accuracy of the standards.

The DRY data set was used to evaluate linear equations for $\mathrm{M}_{\mathrm{E}}$ and $\mathrm{N}_{\mathrm{E}}$ published by Wilkerson et al. (1997). Dry cows were assumed $230 \mathrm{~d}$ pregnant because day of pregnancy was not available in the dry cow data set. When the Wilkerson et al. (1997) equation $\left[\mathrm{M}_{\mathrm{E}}=\right.$ $(0.00711 \times \mathrm{BW})+(32.4 \times$ Dietary $\mathrm{CP}, \mathrm{g} / \mathrm{g}$ of $\mathrm{DM})+(25.9$ $\times$ Dietary NDF, g/g of DM) +8.05 ] was evaluated there were no mean or linear biases $(P>0.13)$ and the equation accurately described the cows in this small data set. Therefore, the Wilkerson et al. (1997) equation could be used for prediction of $\mathrm{M}_{\mathrm{E}}$ for dry cows. Conversely, evaluation of the $\mathrm{N}_{\mathrm{E}}$ equation $\left[\mathrm{N}_{\mathrm{E}}=(0.000107 \times \mathrm{BW})\right.$ $+(1.11 \times$ Dietary CP, g/g of DM $)+(0.170 \times$ Dietary NDF, $\mathrm{g} / \mathrm{g}$ of DM) - 0.135] (Wilkerson et al., 1997) resulted in mean $(0.2795 \mathrm{~kg} / \mathrm{d} ; P<0.01)$ and linear biases $(1.19 ; P<$ $0.01)$. The mean and linear biases indicate that updated regression equations need to be developed to adequately predict $\mathrm{N}_{\mathrm{E}}$ from dry cows. In the future, more research is needed on dry cows fed diets typical in the industry, to be able to develop regression equations.

\section{Heifers}

The data set for heifers included 60 observations ranging in BW from 274 to $613 \mathrm{~kg}$ (Table 2). The 2001 ASAE manure excretion estimates for dairy cattle were not categorized by animal age. Excretion estimates for heifers were not specifically available and would have to be approximated using either dairy cattle or beef cattle data. Determination of new prediction equations for growing dairy heifers was difficult due to a shortage of total collection metabolism trials recently conducted on this class of animals.

Manure excretion in the HEIFER data set was overestimated by $\sim 54 \%$ for the average heifer $(437 \mathrm{~kg})$ using the 2001 ASAE dairy excretion estimates, but by only $\sim 3 \%$ using the beef estimates. The most accurate equation for predicting $\mathrm{M}_{\mathrm{E}}$ for heifers included $\mathrm{BW}$ and DMI [14]. Manure excretion was dependent on BW of the animal alone [15], although the addition of DMI to the equation provided a more precise predictor of $\mathrm{M}_{\mathrm{E}}$. 


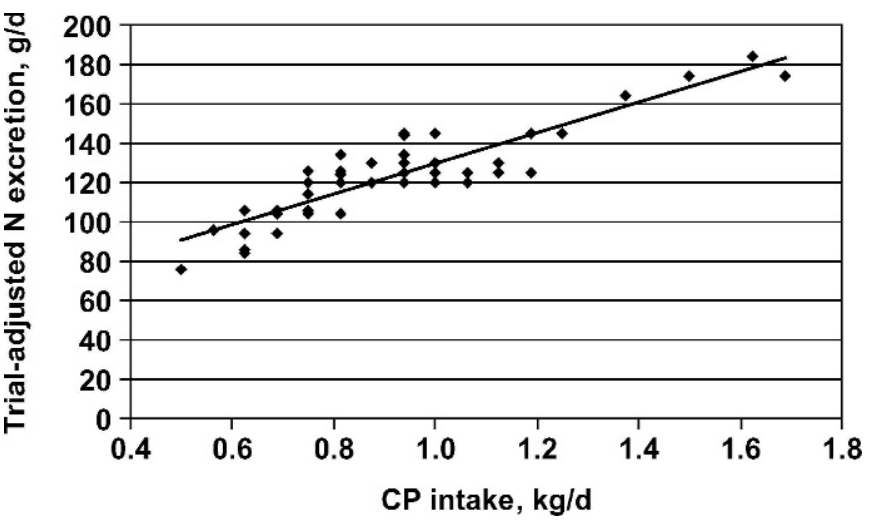

Figure 3. Relationship between $\mathrm{CP}$ intake and trial-adjusted $\mathrm{N}$ excretion for heifers (60 animal-periods). The solid line is equal to $\mathrm{N}$ excretion, $\mathrm{g} / \mathrm{d}=(\mathrm{CP}$ intake, $\mathrm{kg} / \mathrm{d} \times 78.39)+51.4 ;$ Residual $\mathrm{SE}=10.8$, interstudy $\mathrm{SE}=24.5$.

$$
\begin{aligned}
\mathrm{M}_{\mathrm{E}}=[\mathrm{DMI} \times 4.158( \pm 0.536)]-[\mathrm{BW} \\
\times 0.0246( \pm 0.0103)]
\end{aligned}
$$

Residual $\mathrm{SE}=2.6$; interstudy $\mathrm{SE}=5.6$

$$
\begin{gathered}
\mathrm{M}_{\mathrm{E}}=[\mathrm{BW} \times 0.0181( \pm 0.0104)]+17.8( \pm 4.8) \\
\text { Residual } \mathrm{SE}=3.6 ; \text { interstudy } \mathrm{SE}=4.0
\end{gathered}
$$

Nitrogen excretion from dairy heifers in the HEIFER data set averaged $0.1173 \mathrm{~kg} / \mathrm{d}$, which was 0.0804 and $0.0313 \mathrm{~kg} / \mathrm{d}$ less than predicted by the $2001 \mathrm{ASAE}$ dairy and beef values, respectively. An equation [16] developed for $\mathrm{N}_{\mathrm{E}}$ using the HEIFER data set increased $\mathrm{N}_{\mathrm{E}}$ when CP intake increased (Figure 3).

$$
\begin{aligned}
& \mathrm{N}_{\mathrm{E}}=[\mathrm{DMI} \times \text { Dietary CP }, \text { g/g of DM } \\
& \quad \times 78.39( \pm 13.01)]+51.4( \pm 17.0)
\end{aligned}
$$

Residual SE $=10.8$; interstudy $\mathrm{SE}=24.5$

Hoffman et al. (2001), James et al. (1999), and Wilkerson et al. (1997) also reported increased $\mathrm{N}_{\mathrm{E}}$ for heifers fed greater levels of N. Hoffman et al. (2001) found that growth of Holstein heifers was optimized when the dietary CP concentration was $0.13 \mathrm{~g} / \mathrm{g}$ of DM. The average dietary $\mathrm{CP}$ concentration was $0.112 \mathrm{~g} / \mathrm{g}$ of DM in the HEIFER data set (Table 2). Feeding heifers diets with a CP concentration of $0.13 \mathrm{~g} / \mathrm{g}$ of $\mathrm{DM}$ would be expected to increase $\mathrm{N}_{\mathrm{E}}$ compared with the average in the HEIFER data set.

Development of prediction equations for $\mathrm{P}_{\mathrm{E}}$ in the HEIFER data set was not possible due to the limited data available and the variation within the data set.
Previously developed prediction equations for $\mathrm{M}_{\mathrm{E}}$ and $\mathrm{N}_{\mathrm{E}}$ in heifers were evaluated. When the equation for $\mathrm{M}_{\mathrm{E}}\left[\mathrm{M}_{\mathrm{E}}=(0.0499 \times \mathrm{BW})+(44.2 \times\right.$ Dietary $\mathrm{CP}, \mathrm{g} / \mathrm{g}$ of DM $)$ $+(5.86 \times$ Dietary NDF, $g / g$ of DM) -5.918 ] (Wilkerson et al., 1997) was evaluated, there were no mean or linear biases, indicating that this previously published equation adequately described the heifers in this data set. Evaluation of a previously published (Wilkerson et al., 1997) $\mathrm{N}_{\mathrm{E}}$ equation $\left[\mathrm{N}_{\mathrm{E}}=(0.000471 \times \mathrm{BW})+(0.867 \times\right.$ Dietary CP, g/g of DM $)-(0.0109 \times$ Dietary NDF, g/g of DM) - 0.159] from heifers resulted in no linear bias, but there was a trend $(P<0.07)$ toward a mean bias. The mean bias for the equation was $0.1212 \mathrm{~kg} / \mathrm{d}$, indicating an underprediction of $\mathrm{N}_{\mathrm{E}}$ from animals in the HEIFER data set.

\section{Calves}

The data set for calves included 46 observations ranging in BW from 86 to $205 \mathrm{~kg}$ (Table 2). Development of equations for excretion estimates from calves used a small data set because of a shortage of calf data from total collection metabolism studies. As with heifers, estimates of excretion for calves were not available in the 2001 ASAE manure excretion estimates for dairy cattle. Use of the 2001 ASAE manure excretion estimates for calves would not be expected to be accurate for estimating $\mathrm{M}_{\mathrm{E}}$ or nutrient excretion.

Average $\mathrm{M}_{\mathrm{E}}$ from the CALF data set was approximately half the $\mathrm{M}_{\mathrm{E}}$ of the HEIFER data set $(12.1 \mathrm{~kg} / \mathrm{d}$ less), even though the average calf BW was about onethird as much as the heifers (Tables 2 and 5). The most accurate equation for predicting $\mathrm{M}_{\mathrm{E}}$ of calves included DMI [17].

$$
\mathrm{M}_{\mathrm{E}}=[\mathrm{DMI} \times 3.45( \pm 0.41)]
$$

$$
\text { Residual } \mathrm{SE}=5.5 ; \text { interstudy } \mathrm{SE}=2.5
$$

Although DMI was the best predictor of $\mathrm{M}_{\mathrm{E}}$ for the CALF data set, BW was also a predictor of $\mathrm{M}_{\mathrm{E}}(P<$ 0.01) [18].

$$
\mathrm{M}_{\mathrm{E}}=[\mathrm{BW} \times 0.0811( \pm 0.0086)]
$$

Residual $\mathrm{SE}=5.6$; interstudy $\mathrm{SE}=2.1$

Prediction of $\mathrm{DM}_{\mathrm{E}}$ was similar to $\mathrm{M}_{\mathrm{E}}$ for calves. Equation [19] shows the relationship between $\mathrm{DM}_{\mathrm{E}}$ and DMI for the CALF data set, with greater $\mathrm{DM}_{\mathrm{E}}$ occurring as DMI increases.

$$
\mathrm{DM}_{\mathrm{E}}=[\mathrm{DMI} \times 0.393( \pm 0.032)]
$$

Residual SE $=0.31$; interstudy $\mathrm{SE}=0.24$ 


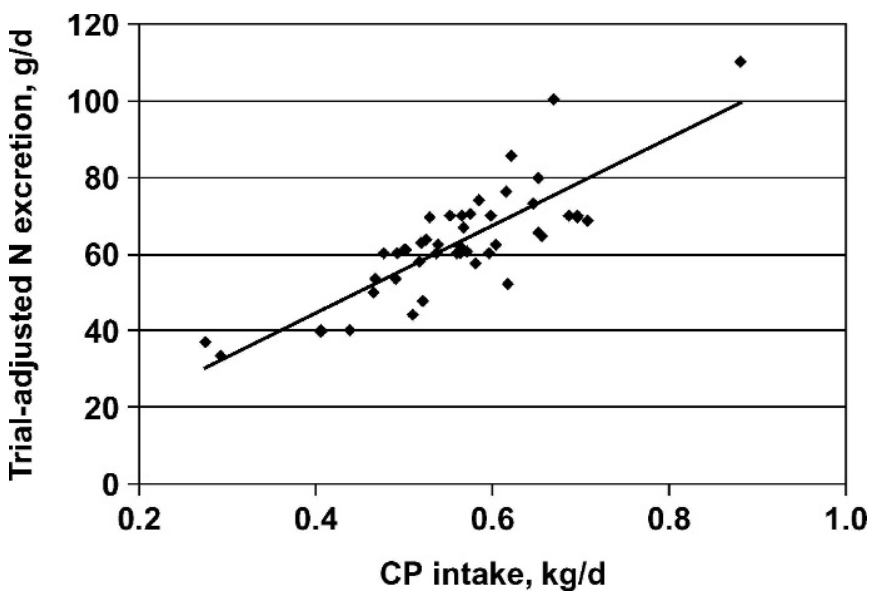

Figure 4. Relationship between $\mathrm{CP}$ intake and trial-adjusted N excretion for calves (46 animal-periods). The solid line is equal to $\mathrm{N}$ excretion, $\mathrm{g} / \mathrm{d}=(\mathrm{CP}$ intake, $\mathrm{kg} / \mathrm{d} \times 112.55)$; Residual $\mathrm{SE}=8.2$.

Nitrogen excretion was directly related to CP intake in the CALF data set [20] as it was for the other classes of dairy animals. In the CALF data set, the coefficient for CP intake was greater than was seen in the HEIFER data set (112.6 and 78.4, respectively) for the simple linear equation to predict $\mathrm{N}_{\mathrm{E}}$ (Figures 3 and 4).

Evaluation of [20] with the HEIFER data set resulted in a linear bias of $-0.873(P<0.01)$ and a mean bias of $-0.0797 \mathrm{~kg} / \mathrm{d}(P<0.01)$ of excreted $\mathrm{N}$. The mean bias indicated that $\mathrm{N}_{\mathrm{E}}$ for heifers would be overestimated if [20] was used to predict $\mathrm{N}_{\mathrm{E}}$.

$$
\begin{gathered}
\mathrm{N}_{\mathrm{E}}=[\mathrm{DMI} \times \text { Dietary } \mathrm{CP}, \mathrm{g} / \mathrm{g} \text { of } \mathrm{DM} \\
\times 112.55( \pm 2.13)] \\
\text { Residual } \mathrm{SE}=8.2
\end{gathered}
$$

A relationship between $P$ intake and $P_{E}$ was seen in the CALF data set (Figure 5) even though there was not a relationship $(P>0.25)$ in the HEIFER data set. Phosphorus excretion increased with greater $\mathrm{P}$ intakes in the CALF data set [21].

$$
\begin{gathered}
\mathrm{P}_{\mathrm{E}}=[\mathrm{DMI} \times \text { Dietary P, g/g of DM } \\
\times 622.03( \pm 37.58)]
\end{gathered}
$$

Residual SE $=1.44$; interstudy $\mathrm{SE}=0.57$

Although there was not a direct relationship between $\mathrm{P}_{\mathrm{E}}$ and $\mathrm{P}$ intake in the HEIFER data set, when equation [21] was evaluated in the HEIFER data set, there were no mean or linear biases. Because [21] accurately predicted the $\mathrm{P}_{\mathrm{E}}$ from HEIFERS, this equation could be used for nonlactating heifers regardless of BW.

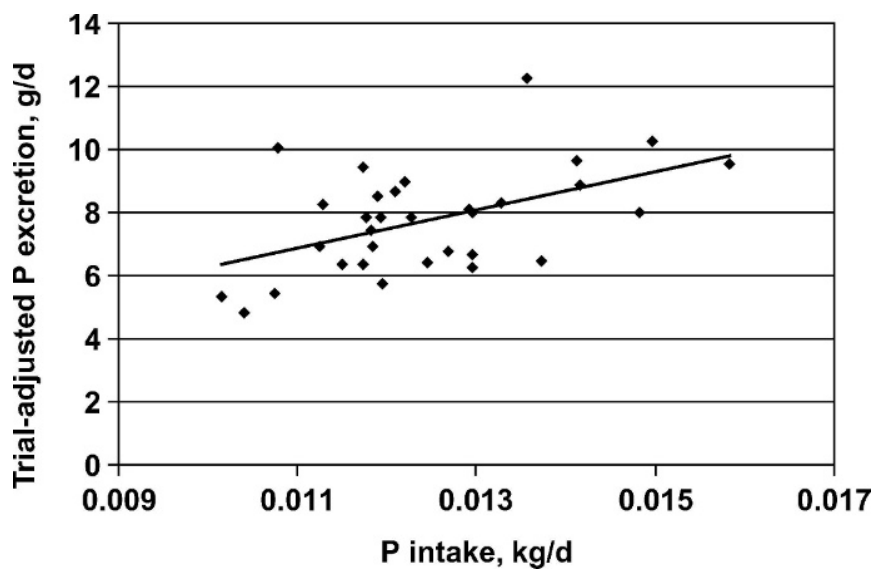

Figure 5. Relationship between $P$ intake and trial-adjusted $P$ excretion for calves (32 animal-periods). The solid line is equal to $\mathrm{P}$ excretion, $\mathrm{g} / \mathrm{d}=(\mathrm{P}$ intake, $\mathrm{kg} / \mathrm{d} \times 622.03)$; Residual $\mathrm{SE}=1.4$, interstudy $\mathrm{SE}=0.6$.

\section{CONCLUSIONS}

The proposed revisions of the ASAE manure excretion estimates for dairy cattle provide updated values that more closely reflect the excretion values of contemporary animals as well as providing excretion estimates for various classes of animals, including heifers and dry cows. The 2001 ASAE standards underestimate manure and $\mathrm{N}$ excretion from high-producing dairy cows and overestimate manure and nutrient excretion from dry cows, calves, and heifers. The most significant change to the 2001 ASAE standards included the addition of prediction equations, which provide a method by which excretion estimates can be determined according to production levels and dietary factors for a given operation. The improved ability to predict nutrient excretion will be essential information for technical service providers and producers to consider when developing nutrient management plans.

\section{ACKNOWLEDGMENTS}

The authors would like to thank the National Center for Manure and Animal Waste Management (Raleigh, NC), and Church \& Dwight, Co. (Princeton, NJ) for the financial support provided for sample analyses.

\section{REFERENCES}

American Society of Agriculture Engineers (ASAE). 2001. Manure production and characteristics. ASAE Standards D384.1. ASAE, St. Joseph, MI.

Beede, D. K., and J. A. Davidson. 1999. Phosphorus: Nutritional management for Y2K and beyond. Pages 51-97 in Tri-State Dairy Nutr. Conf., Ft. Wayne, IN. The Ohio State Univ., Columbus, OH.

Environmental Protection Agency. 2003. National pollutant discharge elimination system permit regulation and effluent limita- 
tion guidelines and standards for concentrated animal feeding operations (CAFOs). Final Rule. Fed. Regist. 68:7176-7274.

Frank, B., M. Person, and G. Gustafsson. 2002. Feeding dairy cows for decreased ammonia emission. Livest. Prod. Sci. 76:171-179.

Gabler, M. T., and A. J. Heinrichs. 2003a. Altering soluble and potentially degradable protein for prepubertal Holstein heifers. J. Dairy Sci. 86:2122-2130.

Gabler, M. T., and A. J. Heinrichs. 2003b. Effects of increasing dietary protein on nutrient utilization in heifers. J. Dairy Sci. 86:2170-2177.

Harrison, J. H., L. Johnson, J. Werkhoven, A. Werkhoven, S. Werkhoven, M. Vazquez-Anon, G. Winter, N. Barney, and W. Chalupa. 2002. Effectiveness of strategic ration balancing on efficiency of milk protein production and environmental impact. J. Dairy Sci. 85(Suppl. 1):205. (Abstr.)

Hoffman, P. C., N. M. Esser, L. M. Bauman, S. L. Denzine, M. Engstrom, and H. Chester-Jones. 2001. Short communication: Effect of dietary protein on growth and nitrogen balance of Holstein heifers. J. Dairy Sci. 84:843-847.

James, T., D. Meyer, E. Esparza, E. J. DePeters, and H. Perez-Monti. 1999. Effects of dietary nitrogen manipulation on ammonia volatilization from manure from Holstein heifers. J. Dairy Sci. 82:2430-2439.

Johnson, L. M., J. H. Harrison, and R. E. Riley. 1998. Estimation of the flow of microbial nitrogen to the duodenum using urinary uric acid or allantoin. J. Dairy Sci. 81:2406-2420.

Krober, T. F., D. R. Kulling, H. Menzi, F. Sutter, and M. Kreuzer. 2000. Quantitative effects of feed protein reduction and methionine on nitrogen use by cows and nitrogen emission from slurry. J. Dairy Sci. 83:2941-2951.

Mackle, T. R., D. A. Dwyer, K. L. Ingvartsen, P. Y. Chouinard, J. M. Lynch, D. M. Barbano, and D. E. Bauman. 1999. Effects of insulin and amino acids on milk protein concentration and yield from dairy cows. J. Dairy Sci. 82:1512-1524.

Meyer, D., V. Erikson, E. Tooman, and T. James. 2000. Manure production characteristics from lactating Holsteins. Proc. West- ern Section ASAS, Davis, CA. J. Anim. Sci. 78 (Suppl. 2):118. (Abstr.)

National Research Council. 2001. Nutrient Requirements of Dairy Cattle. 7th rev. ed. Natl. Acad. Sci., Washington, DC.

Natural Resources Conservation Service (NRCS). 2001. Nutrient management. Natural Resources Conservation Service Conservation Practice Standard Code 590-1. USDA-NRCS, Spokane, WA.

SAS Institute. 1999. SAS User's Guide. Statistics, Version 8.2. SAS Inst., Inc., Cary, NC.

Silanikove, N., E. Maltz, A. Halevi, and D. Shinder. 1997. Metabolism of water, sodium, potassium, and chlorine by high yielding dairy cows at the onset of lactation. J. Dairy Sci. 80:949-956.

St-Pierre, N. R. 2001. Integrating quantitative findings from multiple studies using mixed model methodology. J. Dairy Sci. 84:741-755.

St-Pierre, N. R. 2003. Reassessment of biases in predicted nitrogen flows to the duodenum by NRC 2001. J. Dairy Sci. 86:344-350.

Timmermans, S. J., Jr., L. M. Johnson, J. H. Harrison, and D. Davidson. 2000. Estimation of the flow of microbial nitrogen to the duodenum using milk uric acid or allantoin. J. Dairy Sci. 83:1286-1299.

Tomlinson, A. P., W. J. Powers, H. H. Van Horn, R. A. Nordstedt, and C. J. Wilcox. 1996. Dietary protein effects on nitrogen excretion and manure characteristics of lactating cows. Trans. ASAE 39:1441-1448.

Van Horn, H. H., A. C. Wilkie, W. J. Powers, and R. A. Nordstedt. 1994. Components of dairy manure management systems. J. Dairy Sci. 77:2008-2030.

Weiss, W. P., and D. J. Wyatt. 2004. Macromineral digestion by lactating dairy cows: Estimating phosphorus excretion via manure. J. Dairy Sci. 87:2158-2166.

Wilkerson, V. A., D. R. Mertens, and D. P. Casper. 1997. Prediction of excretion of manure and nitrogen by Holstein dairy cattle. J. Dairy Sci. 80:3193-3204.

Zanton, G. I., and A. J. Heinrichs. 2003. Altering protein degradability and solubility on rumen fermentation, blood urea nitrogen, and nitrogen balance in 16-18 month-old heifers. J. Dairy Sci. 86(Suppl. 1):22. (Abstr.) 